British India by Hooker (1872-1897) and the Flora of the

\title{
Phyllanthus KozhiKodianus SIVAR. \& MANI. (EUPHORBIACEAE) - A NEW RECORD FOR THE STATE OF ANDHRA PRADESH, INDIA
}

\section{P.S. Udayan, K.V. Tushar, Satheesh George and Indira Balachandran}

Centre for Medicinal Plants Research (CMPR), Arya Vaidya Sala, Changuvetty, Kottakkal, Malappuram District, Kerala 676503, India Email: avscmpr@sify.com / avscmpr@yahoo.co.in

web supplement

The Tirumala hill is situated near Tirupati in southen part of the Eastern Ghats between $13^{\circ} 40^{\prime} \mathrm{N} \& 79^{\circ} 21^{\prime} \mathrm{E}$. The Eastern Ghats are the outgrowth of the lower Vindhyan and the Cuddapah systems. In the northern portion, the Ghats are highly dissected and intervened by a number of valleys. The width of this place is between 60 and $70 \mathrm{~km}$ and in many parts, the elevation reaches above $1200 \mathrm{~m}$. The Papikonda range in the north joins Simhachalam. Veering further south-west they form the Cuddapah range of hills called variously Palakondas, Velikondas, Erramalais, Nallamalais, Lankamalais and Seshachalam. They vary in elevation between 600 and $1350 \mathrm{~m}$. The Tirumala hills is floristically rich by virtue of its geographical location, varied forest types, different bio-climatical features, soil and topography. It is also one of the important centres of endemism in the Eastern Ghats. Tirumala forest is vegetationally very rich and socio-religiously important. The famous Tirumala Tirupati Venkateswara temple is situated within this forest. The altitude ranges from 650 to $1000 \mathrm{~m}$. The forest type is South Indian tropical moist deciduous according to Champion and Seth's classification (1968). The soil type is red, derived from the weathering of gneisses and granite and covers about 70 percent of the total area of the state.

Previous botanical explorations: Earlier floristic work along peninsular India began with Plants of the Coromandel Coast by William Roxburgh (1795-1819) and followed by other works by Wight (1839-1853), Elliot (1859), Beddome (1869-74), Gamble (1915-36) and a few others. William Roxburgh presented 300 colour plates of the plants of the Coromandel coast published in 12 parts (each of 25 plates) from 1795 to 1820 and this was a fore runner to his Flora India. Robert Wight (1839-1853), made extensive collections especially in the southern region of peninsular India and described 38 genera and more than 3000 species of Indian plants. His contribution to Indian botany include about 28 publications of which Illustrations of Indian Botany (1831), Icones Plantarum Indiae Orientalis (1838-53), Spicilegium Neilgherrense (1846-51) are invaluable for the students of plant taxonomy in India Elliot (1859), in his Flora Andhrica gave vernacular and botanical lists of plants commonly met within the Telugu districts of the Northern Circars. Beddome (1869-74), extensively studied the flowering plants of Andhra Pradesh and his publications include The Flora Sylvatica for Southern India which contains quarto plates of all the principal timber trees in southern India and Sri Lanka along with their description as well as analysis of genus not figured in plates. Other early publications are The Flora of
Presidency of Madras by Gamble (1915-1936), both cover the whole state of Andhra Pradesh but the information available in them is incomplete. A few others like Rao $(1958,1964)$ published two papers on Observation on the vegetation of Rampa and Guden agency tracts of Eastern Ghats. Naidu and Rao (1966) listed 979 species of dicotyledonous plants from Cuddapah district. They also contributed to the flora of Tirupati hills in 1967 and 1969. Naidu et al. in 1971 published another paper on the flora of Tirupati hills and they reported about 828 species and two varieties. Narayana Rao et al. (1981) surveyed the flora of Tirumala hills and reported the occurrence of about 1500 species belonging to 176 families. Of these the angiosperms are represented by 1430 species. They also wrote a booklet Plant wealth of Tirumala. More recently Reddy et al. (1991) in their book Forest Flora of Andhra Pradesh listed 2141 wild and cultivated species belonging to 211 families occurring in the forests of Andhra Pradesh. These include 2100 species of angiosperms. Pullaiah and Chennaiah (1997), Pullaiah and Ali Moulali (1997) published the Flora of Andhra Pradesh in 3 volumes and they reported nearly 2531 species belonging to 700 genera represented by 125 families.

Phyllanthus kozhikodianus Sivar. \& Mani. has not been reported from Andhra Pradesh in any of the previous publications. It is enumerated here with updated nomenclature, brief description, phenological data, distribution, specimen examined and notes for better understanding of this taxon. The voucher specimens are deposited at the Centre for Medicinal Plants Research (CMPR), Kottakkal.

\section{Phyllanthus kozhikodianus Sivar. \& Mani.}

Jour. Ind. Bot. Soc. 56: 165-168. 1977; Sivar. \& Joseph, J. Bombay Nat. Hist. Soc. 17: 369. 1981; Manilal \& Sivarajan, Fl. Calicut 264. 1982; Manilal et al., Fl. Silent Valley 254. 1988; Sasi. \& Sivar., Fl. Thrissur Forests 413. 1996; Nayar, Hot Spots of End. Pl. India, Nepal \& Bhutan 212. 1996. Sivarajan \& Philip Mathew, Fl. Nilambur 639. 1997; Udayan et al., Zoos' Print J. 20(6): 1904. 2005. (Euphorbiaceae)

Distribution: Endemic to Kerala, Tamil Nadu (Udayan et al., 2005) and East Himalayas (Sivarajan \& Joseph, 1981).

Description: Erect annual herbs, up to $60 \mathrm{~cm}$ tall. Leaves elliptic or obovate, glabrous, $2.5 \times 1.5 \mathrm{~cm}$, obtuse to sub acute at apex, rounded at base; lateral nerves obscure; petioles ca $1 \mathrm{~mm}$ long. Male flowers greenish-white, $2.5 \times 1.5 \mathrm{~mm}$ across, in axillary fascicles of 2-3; tepals six, sub equal; outer three ovate, acute at apex; inner three ovate, obtuse at apex; stamens three, filaments connate, anthers dehiscing transversely; disc glands six, star-shaped. Female flowers green with prominent white margins, 3-4 x 3mm across, solitary, axillary; tepals six, same as male flowers, styles three, spreading, disc glands six, linear. Capsules depressed globose, ca. 8 x $3 \mathrm{~mm}$, glabrous, with accrescent long tepals. Seeds trigonous, vertically striate (Image $\left.1^{\mathrm{w}}\right)$.

Habitat: Common in moist deciduous to evergreen forests.

w See Image 1 in the web supplement at www.zoosprint.org

(c) Zoo Outreach Organisation; www.zoosprint.org Manuscript 1469; Received 28 November 2005; Finally accepted 04 March 2006; Date of publication 21 April 2006 
Phenology: Flowers and fruits almost throughout the year.

Specimen examined: Udayan et al., 03752, Narayanagiri, near Tirumala, Chittoor district, Andhra Pradesh, on 20.10.05, $\pm 1020 \mathrm{~m}$ altitude. A good population of mature individuals was observed in the study area.

Biotic association: This endemic herb is common and found to grow near moist and shady localities of semievergreen forests. It grows along with Ampelocissus latifolia (Roxb.) Planch (Vitaceae); Clitoria ternatea L. and Rhynchosia beddomei Baker (Fabaceae); Cycas beddomei Dyer (Cycadaceae); Decaschistia crotonifolia Wight \& Arn. (Malvaceae); Hemidesmus indicus (L.) R.Br. (Periplocaceae); Mallotus philippensis (Lam.) Muell.Arg. (Euphorbiaceae); Pimpinella tirupatiensis Balakr. \& Subr. (Apiaceae); Sida acuta Burm.f. (Malvaceae) and Syzygium alternifolium (Wight) Walp. (Myrtaceae). etc.

Notes: This endemic species was earlier reported from Calicut, Silent Valley of Palakkad, Thrissur and Malappuram districts of Kerala (Sivarajan \& Manilal, 1977; Manilal \& Sivarajan, 1982; Manilal et al., 1988; Sasidharan \& Sivarajan, 1996; Sivarajan \& Mathew, 1997). It was reported from northeastern India (Sivarajan \& Joseph, 1981). Udayan et al. (2005) reported this species from Shevaroy Hills of Salem district as a new report to the state of Tamil Nadu which extended its distribution to the Eastern Ghats. Flora of Andhra Pradesh by Pullaiah and Ali Moulali (1997), which mostly covers the flora of Eastern Ghats, has not mentioned the occurrence of this species in Andhra Pradesh. So far none of the published floras of Andhra Pradesh has reported this species. The present collection from Narayanagiri hills, near Tirumala not only extends its distribution to the northern part of Eastern Ghats but also forms a new report to the state of Andhra Pradesh. It can be easily distinguished from the other herbaceous species of Phyllanthus in having more than $2 \times 1.5 \mathrm{~cm}$ leaf size, connate anthers and fruiting perianth lobes that are as long as the capsule (Sivarajan \& Manilal, 1982). Medicinal properties of this species are not known. The voucher specimens of this species were critically studied at CALI Herbarium, Calicut University and are deposited in the herbarium of Centre for Medicinal Plants Research, (CMPR), Arya Vaidya Sala, Kottakkal, Malappuram, Kerala.

\section{REFERENCES}

Beddome, R.H. (1868-1874). Icones Plantarum Indiae Orientals. Gantz Brothers, Madras.

Beddome, R.H. (1869-1874). The Flora Sylvatica for Southern India. Gantz Brothers, Madras.

Champion, H.G. and S.K. Seth (1968). A Revised Survey of the Forest Types of India. Forest Research Institute Publications, Delhi.

Elliot, W. (1859). Flora Andhrica. Madras.

Gamble, J.S. and C.E.C. Fischer (1915-1935). Flora of the Presidency of Madras. London. (Reprinted 1957), Calcutta.

Hooker, J.D. (ed.) (1872-1897). Flora of British India (7 vols.), London.

Manilal, K.S. (1988). Flora of Silent Valley Tropical Rain Forests of India. Calicut University, Calicut.

Manilal, K.S. and V.V. Sivarajan (1982). Flora of Calicut. Bishen Singh Mahendra Pal Singh, Dehra Dun.

Naidu, K.V. and R.S.P. Rao (1966). Flora of Cuddapah district
Dicotyledons. Diocesan Press, Madras.

Naidu, K.V. and R.S.P. Rao (1967). A contribution to the Flora of Tirupathi Hills, Part-I. Ind. For. 93: 123-125.

Naidu, K.V. and R.S.P. Rao (1969). A contribution to the Flora of Tirupathi Hills, Part-II. Ind. For. 95: 123-125.

Naidu, K.V., P.M. Swamy and K.N. Rao (1971). Contributions to the Flora of Tirupathi Hills, Part III. Ind. For. 97: 89-100.

Narayana R., K. Thammanna and K.S.R. Das (1981). Plant Wealth of Tirumala, T.T.D. Press

Pullaiah, T. and D.A. Moulali (1997). Flora of Andhra Pradesh (India). Vol. 2. Scientific Publishers, Jodhpur.

Rao, R.S. (1958, 1964). Observation on the vegetation of the Rampa and Gudem Agency tracts of the Eastern Ghats. I \& II. Journal of the Bombay Natural History Society 55: 429-499, 61: 303-329.

Reddy, R.D., M.K. Prasad and K. Venkaiah (1991). Forest Flora Andhra Pradesh. (Vernacular names). Hyderabad.

Roxburgh, W. (1795-1810). Plants of the coast of Coromandal. London.

Roxburgh, W. (1814). Hortus Benghalensis. Serampore.

Roxburgh, W. (1832). Flora Indica. Serampore.

Sasidharan, N. and V.V. Sivarajan (1996). Flowering Plants of Thrissur forests (Western Ghats, Kerala, India). Scientific Publishers, Jodhpur.

Sivarajan, V.V. and P. Mathew (1997). Flora of Nilambur (Western Ghats, Kerala). Bishen Singh Mahendra Pal Singh, Dehra Dun.

Udayan, P.S., K.V. Tushar, S. George, A.K. Pradeep and I. Balachandran (2005). "Phyllanthus kozhikodianus Sivar. \& Mani. (Euphorbiaceae) - a new record for the state of Tamil Nadu, India" Zoos' Print Journal 20(6): 1904.

Wight, R. (1834). Contributions to the Botany India. London.

Wight, R. (1838-1853). Icones plantarum Indiae Orientalis. Madras. Wight, R. (1840-1850). Illustrations to Indian Botany. London.

\section{ACKNOWLEDGEMENTS}

The authors are thankful to the authorities of Arya Vaidya Sala, Kottakkal and Department of Biotechnology, Government of India, for the financial support. We are also greatly indebted to Dr. P.N. Ravindran, Visiting Scientist, CMPR for his constant encouragement and support. We express our gratitude to the authorities of Tirumala, Tirupati Devasam (T.T.D), Mr. A.P.V. Narayana Sharma, I.A.S., Executive Officer T.T.D, for granting permission for the field visit. Thanks are also due to Dr. Madhava Chetty, Herbarium keeper, Sri Venkateswara University, Tirupati and Mr. N.K. Janardhanan, Herbal Garden staff, for assisting during the field visit.

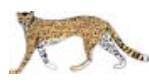

